\title{
1. Reckoning contract damages: valuation of the contract as an asset
}

When a contract is breached the law typically provides some version of the aphorism that the nonbreaching party should be made whole. The Uniform Commercial Code (UCC) provides that " $\mathrm{t}]$ he remedies provided by this Act shall be liberally administered to the end that the aggrieved party may be put in as good a position as if the other party had fully performed" (UCC §1-305). The English version, going back to Robinson $v$ Harman, is "that where a party sustains a loss by reason of breach of contract, he is, so far as money can do it, to be placed in the same situation, with respect to damages, as if the contract had been performed" (at 855). Similarly, under Article 74 of the United Nations Convention on Contracts for the International Sale of Goods (CISG), "damages are based on the principle that damages should provide the injured party with the benefit of the bargain, including expectation and reliance damages." However, application of the aphorism has proven more problematic. In this chapter, I propose a general principle that should guide application - the contract is an asset and the problem is one of valuation of that asset at the time of the breach. This provides, I argue, a framework that will help clear up some conceptual problems in damage assessment. In particular, it will integrate three concepts - cover, lost profits, and mitigation - under the asset valuation umbrella.

Consider three patterns in which a contract might be breached. In the first, the breach occurs at the time of performance. That is the simplest case. The second is an anticipatory repudiation in which the breach occurs before the time for performance, and the litigation takes place after the date of performance. Finally, the third involves a breach of a long-term contract, the performance of which was to continue past the date the litigation would be resolved. At what point should damages be reckoned? I will argue that at the moment of breach or repudiation, the damages would be the change in the value of the contract (the asset). That implies that when assessing damages, to the extent that it is possible, post-breach facts should be ignored.

Let us begin with the simple case. Suppose that Sam Smith agrees to sell 1,000 shares of Widgetco stock to Betsy Brown for delivery on June 1 at $\$ 10$ per share. On June 1, the market price is $\$ 16$ and Smith reneges. The case is decided on December 1 (hypothetical courts can work very fast) at which 
time the price has fallen to $\$ 9$. Brown sues for $\$ 6,000$, the contract-market differential at the date of breach. Smith counters, claiming that he had done Brown a favor and that there should be no damages; the $\$ 6,000$ would be a windfall for Brown. Alternatively, suppose that on December 1 the price had risen to $\$ 25$ per share. Brown would now claim that her damages should be measured by the price differential on December 1, and therefore she should receive $\$ 15,000$. Smith would argue that damages should be measured by the differential at the date of breach, June 1. At the time the claim is being litigated, it clearly would matter whether we chose the date of breach or the date of litigation as the appropriate date for assessing damages. But at the time the parties entered into the contract, would it matter?

The forward price at the time of the breach (or repudiation) should be the expected price at the time of the litigation. That is, when entering into the contract, given the choice of remedy between the forward price at the time of breach and the actual price at the time of litigation, parties should be indifferent. Whether we invoke rational expectations, efficient markets, or arbitrage, the conclusion is robust. So, conceptually, we should be indifferent between a rule that says always use the breach date or always use the litigation date - the measurement date should be chosen behind a "veil of ignorance." The existence of a firm rule is more important than the content of the rule. Otherwise, the parties would invoke the rule more favorable to them at the time of the trial and the court would have little guidance in choosing between the proffered measures.

Having said that, I will proceed by choosing the breach date as the appropriate date. The advantage is that the party contemplating nonperformance will find it easier to weigh the costs and benefits of going forward. It is useful to think of the damage remedy as the price of the implicit termination option. Using the breach date makes the price more transparent, making the decision easier (determining that price can still be very difficult, a point that will become clear in section 3).

The first two patterns have received substantial treatment in the literature. Surprisingly, significant scholars, notably J.J. White and Robert Summers in their treatise, have rejected the breach-date rule (\$6.7). With regard to the first, they argue that there is a conflict between the UCC remedies for a buyer's breach. Section 2-706 allows the seller to resell the goods (to cover) while section 2-708(1) gives the contract-market differential. Properly conceived, there is no conflict, as I will show in section 1. With regard to the second, White \& Summers assert that “[m] easuring buyer's damages under 2-713 upon an anticipatory repudiation presents one of the most impenetrable interpretive problems in the entire Code" (at 237). The difficulties, as we shall see in Part II, arise because of a failure to adopt the breach-date rule. Not all the commentary has followed White \& Summers' position. Robert Scott (1990) 
argued for the breach-date rule regarding the first pattern a generation ago and Tom Jackson (1978) did the same for anticipatory repudiation even earlier. My analysis of these two cases parallels theirs. Sections 1 and 2 of this chapter will be devoted to these two problems.

The third pattern, which has attracted much less scholarly attention, raises a number of problems not present in the first two. How, if at all, should the damage measurement take account of possible losses that might occur post-decision? Should damages for breach of an installment be determined in the same manner as an anticipatory repudiation? In a take-or-pay or minimum quantity contract, should there be different damage theories for a failure to take as opposed to an anticipatory repudiation of the contract? The case law, particularly regarding take-or-pay contracts, has been extremely muddled. In section 3, I will clarify the issues. Central to the argument is that, for an anticipatory repudiation, the focus should be on the change in the value of the contract at the time of the breach. The analysis will also shed light on a classic casebook case-Lake River Corp. v Carborundum Co.

To get a better handle on ascertaining damages in long-term contracts, it is useful to unpack the Widgetco hypothetical. Where does the June 1 share price of \$16 come from? Widgetco's value is not a function of the past; it depends on projecting earnings into the future. All sorts of things might happen that will affect Widgetco's future earnings. Recessions, inflation, war, market shifts, currency fluctuations, pestilence, the health of key personnel, oil embargos, and expropriations all might affect the value of Widgetco. Its current market price reflects the collective best guess as to the likelihood and impact of all of these and any other contingencies. That is, all the uncertainty about the future has been incorporated into a single number: the price. The same methodology can be applied when estimating damages for the anticipatory repudiation of a 20-year take-or-pay contract. The future path of costs, prices, demand, and the many factors alluded to above would also make the future value of the contract uncertain. The inquiry would concern the change in the price of a single asset - the contract - at the time of the event (breach or repudiation). I do not mean to suggest that it would be easy. But the principle is important. The argument will be developed in section 3 .

Throughout this chapter, I will refer to the damage measure as the marketcontract price differential. Because, in practice, there will often not be an actual market price, it might be better to label this the "current-contract" price differential. The reader should feel free to use the two interchangeably.

\section{THE SELLER'S REMEDY FOR BREACH}

In a contract for the sale of goods, when the buyer breaches, the UCC provides two alternative damage remedies; this has led to some confusion. Section 
2-706 allows the seller to resell the goods (to cover), and reckons the damages as the difference between the contract price and the price at which the goods were sold. Section 2-708(1) provides for the market-contract differential. If at the time of a buyer breach the market price had fallen, the buyer's liability would be the market-contract differential. But suppose that the market price subsequently rose and the seller resold the goods at a price greater than the contract price. Some commentators perceive a conflict between 708 and 706, arguing that allowing recovery of the contract-market differential would give the seller a windfall. White \& Summers, while noting that the UCC is unclear, opt for restricting recovery:

Whether the drafters intended a seller who has resold to recover more in damages under 2-708(1) than he could recover under 2-706 is not clear. We conclude that a seller should not be permitted to recover more under 2-708(1) than under 2-706, but we admit we are swimming upstream against a heavy current of implication which flows from the comments and the Code history (\$6.7).

Some courts and other commentators (for example Eisenberg 2013, 398-9) have joined White \& Summers in their concern about a possible windfall. Robert Scott (1990) debunked the idea more than two decades ago, but it still hangs on. I will have another go at it here.

The argument is that awarding the contract-market differential could overcompensate sellers. Consider a simple example: Widgetco promises to sell to Buildco 1,000 tons of widgets for delivery on January 1 for $\$ 100,000$. On January 1, Buildco breaches and the market value is $\$ 70,000$. Damages? $\$ 30,000$. But, Buildco argues, Widgetco didn't sell right away; it held the widgets for four more years, ultimately selling them for $\$ 120,000$. Citing section 2-706, Buildco claims that the resale should be taken into account and that Widgetco didn't lose $\$ 30,000$ after all. Compensating that amount would mean that Widgetco would net $\$ 50,000$ (the $\$ 30,000$ remedy plus the $\$ 20,000$ increase in value), which would be a windfall. So goes the argument.

The widgets four years hence might well be physically identical, but they are not economically identical. At the moment of breach, Widgetco has lost an asset, the right to the net proceeds of sale on January 1. In this case it happens to be a positive amount, $\$ 30,000$. The right to sell widgets on January 1 is not the same as the right to sell physically identical widgets at some subsequent date. Awarding Widgetco $\$ 30,000$ puts it in as good a position as if the other party had fully performed. However, in addition to the $\$ 30,000$ it would still have the widgets, which would be worth $\$ 30,000$ less than they were when the contract was formed. Had it in fact sold the widgets at the market price at the moment of breach, Widgetco would be in exactly the same position as if the 
contract had been performed (ignoring the costs of both finding a new buyer and litigation).

After January 1, it would be free to buy, sell, or use widgets or any other assets. The subsequent course of prices of widgets (or any other assets) bears no relation to what it had lost at the time of the buyer's breach. If it held the widgets, it bore the risk of subsequent price changes. Suppose that in the four years following January 1 it had, at various dates, bought and sold physically identical widgets. The prices of those transactions are as relevant to its damages award as the prices of Widgetco stock or any other assets it might have bought or sold in that subsequent period - namely, no relevance at all. The simple point is this: If the market price information is easily available, the quest for the remedy should be over. If the seller decides to hold, use, eat, or resell the item, that ought to be of no concern to the breaching buyer.

For an amusing example of the correct treatment of the issue in a non-UCC context, see Kearl v Rausser, a double-barreled battle of the experts. One group of economic experts was suing another expert for breach of contract and the experts presented conflicting expert opinions on the damages. The issue concerned the valuation of shares of stock. (When Rausser moved his practice to Charles River Associates (CRA), part of his compensation was a forgivable loan to buy shares of CRA stock. He, in turn, promised to share some of the stock with other economists he brought to CRA. The dispute was over how many shares of CRA stock Rausser had promised the plaintiffs and the valuation of that stock.) After the breach, the stock price had risen and the defendant (Rausser) had sold shares at various dates at prices above the price on the date of breach. The plaintiffs won a jury verdict based on the post-breach sale prices; the Court of Appeals reversed.

Instead of seeking to measure their losses as of the date of Dr. Rausser's breach, plaintiffs were free under the jury instructions given to argue for damages months and even years after any possible breach date. Indeed, plaintiffs' damages theory valued the stock as of the dates of Dr. Rausser's sales and, for the stock he retained, the date of trial (at 605).

If the market price were not so easily available, then the proceeds of resale might come into play. Rather than treat section 2-706 as an alternative or coequal remedy, it is more useful to view it as a possible source of evidence of the market price at the time of the breach. The persuasiveness of the evidence from a subsequent resale would depend on the temporal proximity and on the availability of other evidence. If the seller were to resell promptly that would be good evidence of the market price and the burden should be on the buyer to show that the sale price was unreasonable. If the market were thin, this would be especially important and the buyer's proof burden should be high. So, for 
example, in a well-known casebook case, Columbia Nitrogen's claim that Royster resold its fertilizer at too low a price should have been met with great skepticism. The four years in the hypothetical should certainly not qualify as reasonable evidence.

How does this play out in practice? The Oregon Supreme Court was faced with the problem in a recent case, Peace River Seed Co-Operative, Ltd $v$ Proseeds Marketing, Inc. The seller of grass seed was an agricultural cooperative of grass seed producers. It entered into a number of fixed price contracts with a single buyer to sell fungible seeds over a two-year period. The buyer was to provide shipping and delivery instructions. The market price fell and the buyer refused to provide shipping instructions. After buyer's continued refusal, seller canceled the contracts; the court concluded that the buyer had breached and all that was left was the determination of damages. There is no discussion in the case as to whether the performance date for all the contracts had passed. The court focused on a single contract and I will do likewise.

The contract price was 72 cents per pound. The market price at that time of the breach was 64 cents, so under 2-708 the damages would be 8 cents per pound. However, "[o]ver the next three years, plaintiff was able to sell at least some of the seed that defendant had agreed to purchase to other buyers" (at 47). Some of the contract seed, the buyer claimed, was sold at 75 cents per pound. The decision does not make clear when in that three-year period the seed was sold. The buyer argued that if the seller were awarded the 8 cents it would receive a windfall, since it would also receive the extra 3 cents from the subsequent sale. To further confuse the matter, the court noted that the seller claimed that some of the seed had been sold at 60 cents, which would have resulted in a higher measure of damages. Thus, it appears that over the course of the three years there were a number of sales of seed at different prices. The seller could have sold the seeds at the market price (64 cents) at the time of the breach, but chose not to.

The question was: Should any (or all) of these different prices be recognized when reckoning damages? The trial court chose to recognize at least some of these prices, thereby favoring the buyer. This decision was reversed by the Oregon Court of Appeals and the Oregon Supreme Court upheld that decision. The Oregon Supreme Court based part of its conclusion on a comparison of buyer and seller remedies under the Code. For sellers the available remedies are resale price damages and market price damages. The court noted: "[I]t lists those remedies without any limiting conjunction, such as 'or,' that might suggest that the remedies are mutually exclusive" (at 55). The buyer's remedy, however, only allows for cover or damages for nondelivery. "Thus, although the buyer's index of remedies suggests that a buyer who covers may be precluded from seeking market price damages, the seller's index of remedies does not contain a similar limitation if the seller chooses to resell" (at 55). 
This emphasis on conjunctions exemplifies the confused way the court tackles what turns out to be a simple problem. The issue was not grammar; it was economics.

The disposition of the goods would be relevant only if the market price information were not easily ascertainable. A subsequent sale (or purchase) might provide reasonable evidence of the market price at the time of the breach. The closer in time to the breach, the more plausible the notion that the sale price would be the market price. For complex goods that are not frequently traded - for example, multiyear time charters - the time between breach and ascertaining the market price might be measured in weeks or months. For items sold in fairly thick markets - for example, grass seed - the period might be measured in days or hours. In Peace River, it appears that there were subsequent sales at different prices spread over a three-year period.

If the remedy were based on resale, the parties would identify the sales most favorable to their position. As Ellen Peters (1963, at 257), noted, it is easy to manipulate damages when the seller deals regularly with the market:

The buyer or seller who, by the nature of his business enterprise, constantly enters into new contracts for related goods and services in a market where prices fluctuate broadly and abruptly, will have a wide range of alternatives to substitute for the contract in default. It is only realistic to expect injured claimants to allocate as a substitute contract that which gives rise to the largest amount by way of damages.

It would be a most unusual seller who could not use these openings to create a number of alternative substitutes with which to play.

In its brief, Peace River recognized that at the time of the breach it could have, but need not have, resold immediately and that if it failed to do so, it would bear the risk:

Because the law treats the contract as terminated without any transfer of ownership, the seller remains the owner of the goods. The seller may deal with the goods as it sees fit. The seller may sell the commodities immediately at the "market price" and take the cash. Alternatively, the seller may keep the goods for its own use; hold the commodities for later sale hoping that the price will go up, but taking the risk that the price will go down; or (as Peace River apparently did in part here) largely hold them until they lose all their value (at 16).

It also described one way of ascertaining the market price at the time of the breach:

Peace River presented unopposed testimony that the custom in the industry allowed parties to similar contracts to enter into "wash" transactions under which the seller pretends that it ships the seed and gets the contract price, and the breaching buyer resells the seed to the seller at the current market price. In essence, they "wash" 
the obligation to ship both ways and the breaching buyer pays just the difference between the contract and market price, plus incidental damages. [UCC §2-708(1)] precisely matches that custom. Proseeds itself entered into a three-way "wash" transaction that gave Peace River the difference between its contract price and market price. Doing so acknowledges the custom Peace River's evidence established (at 16).

The wash transaction simply replicated the time-of-the-breach remedy. The only concern would have been whether the market at the time was so thin that the seller could behave opportunistically, claiming a wash price that was more favorable to it than a neutral estimate of the market price.

The value of the contract at the time of the breach was determined by the contract-market differential at that point in time. If the seller did not dispose of the seeds in a timely manner, it bore the risk of subsequent price changes. Properly conceived, there was no conflict between sections 2-706 and 2-708(1). Whether a particular resale did reflect the market price at the time of the breach would have been a fact question. And the court should have concluded that the price of grass seed three years after the breach was stale information.

Neither the decisions nor the briefs in Peace River dealt with the possibility that, when Peace River canceled the remaining deliveries (that is, when the buyer breached), the due dates for performance in those contracts were subsequent to the cancellation. That is, what if the buyer anticipatorily repudiated the contract? That would add a new problem but the principle would remain the same. Suppose that the breach date was January 1 and at the time of the breach, one of the contracts had a delivery date six months later. The relevant market price would be the forward price, the price on January 1 for the goods with a delivery date of June 1. It might turn out that the forward price could not be ascertained directly and the courts might have to resort to other observable prices as evidence - perhaps the market price on either January 1 or June 1 and resale prices at or near those dates might be the best evidence, but we should not lose sight of the basic principle. I will elaborate on that in the section which follows.

\section{ANTICIPATORY REPUDIATION}

In this section, I consider the case in which the court's decision would come after the final date of performance, so the court would have access to all post-termination information. I defer to section 3 the case in which at least some of the performance would have been due after the decision date. Should damages be assessed as of the date the repudiation was accepted, the date that performance was due, or some other date? The law and commentary have been 
mixed. I will argue that damages should be reckoned at the moment when the repudiation has been accepted (or deemed accepted).

Pre-Code cases generally opted for the time of performance. Missouri Furnace Co. $v$ Cochran is a typical pre-Code case. The seller had promised to deliver coke at $\$ 1.20$ per ton on a daily basis for a full year. The market price rose dramatically, and the seller rescinded the contract less than two months after performance had begun. The buyer then immediately entered into a cover contract for the remainder of the year at $\$ 4.00$ per ton (the market rate for a forward contract on that date). However, the market price soon fell to $\$ 1.30$ per ton. The buyer's claim for damages was based on the cover price of $\$ 4.00$, but the court awarded damages on the basis of the spot price of coke on each of the delivery dates. By covering, held the court, the buyer took a risk:

The good faith of the plaintiff in entering into the new contract cannot be questioned, but it proved a most unfortunate venture ... As the plaintiff was not bound to enter into the new forward contract, it seems to me it did so at its own risk, and cannot fairly claim that the damages chargeable against the defendant shall be assessed on the basis of that contract (at 467).

Some post-Code cases have followed this path. I will consider two that illustrate different ways in which the courts have done so. In Cargill, Inc. v Stafford, the seller repudiated a sale of wheat. The buyer, Cargill, claimed damages based on the date at which Cargill accepted the repudiation (September 6) and the trial court accepted that. However, in interpreting the section 2-713 language, "when the buyer learned of the breach," the Tenth Circuit Court of Appeals concluded that this meant "time of performance." In part it relied on pre-Code precedent - "a clear deviation from past law would not ordinarily be accomplished by Code ambiguities." It also relied on the fact that 2-723, which deals with repudiations in which some of the performance would be due after the court's decision, explicitly referred to the time of repudiation, whereas section 2-713 did not. This semantic argument shows up in other cases and in the White \& Summers treatise as well.

Then the argument takes a strange turn. The court asserts that the remedy would depend on whether or not there was a valid reason for the buyer not covering:

We conclude that under $\S 4-2-713$ a buyer may urge continued performance for a reasonable time. At the end of a reasonable period he should cover if substitute goods are readily available. If substitution is readily available and buyer does not cover within a reasonable time, damages should be based on the price at the end of that reasonable time rather than on the price when performance is due. If a valid reason exists for failure or refusal to cover, damages may be calculated from the time when performance is due (at 1227). 
This reflects the notion that cover is a separate remedy, rather than merely evidence of the price at the time of the breach (accepted repudiation). The court remanded, holding:

If Cargill did not have a valid reason, the court's award based on the September 6 price should be reinstated. If Cargill had a valid reason for not covering, damages should be awarded on the difference between the price on September 30, the last day for performance, and the July 31 contract price (at 1227).

So, depending on what had happened to the price in the interim, the parties could argue over whether Cargill had covered; if it had, which transaction was the cover transaction; and if not, the validity of Cargill's reason.

Did Cargill cover? The court says: "The record contains scant, if any, evidence that Cargill covered the wheat" (at 1227). And again: "The record does not show that Cargill covered or attempted to cover. Nothing in the record shows the continued availability or nonavailability of substitute wheat" (at 1226). And so the case was remanded to determine whether Cargill had a valid reason for failing to cover. Cargill, of course, was (and still is) a major player in a thick market. It engages in numerous wheat transactions every day. It makes no sense to identify any particular trade as the cover contract. So, unless the wheat market somehow disappeared on or around September 6, substitute wheat would have been readily available. To even ask whether Cargill covered makes no sense, and it makes even less sense to ask whether the reason for not covering was valid or invalid. Despite the fact that the court appeared to adopt the "time of performance" measure, given its garbled treatment of the cover question, on remand a court could just as well find that (a) a substitute was readily available, (b) Cargill didn't have a valid reason for not covering, and, therefore, (c) the appropriate date would have been the time of repudiation. Or not. Note that the trial court and Cargill used the spot price of wheat on September 6, not the forward price. I will return to this point.

In Hess Energy, Inc. v Lightning Oil Co., Ltd, a seller of natural gas, Lightning, repudiated its agreement. In its defense Lightning made a common fallacious argument, confusing a risen price ex post with a rising price ex ante. Hess, it claimed, "sat idly by during a period of time when they knew the price [of natural gas] was going up, up, up, up, up, up" (at 361). The court ignored this, but, using the same semantic argument as in Cargill, concluded that the Code required that it use the higher price at the time of performance. The case introduced one new complication-Hess's use of the futures market to avoid price risk. The court argued that this would affect how damages should be measured. 
To understand why this would be wrong, it is useful to first reproduce the court's description of Hess's use of the futures market:

Hess' business was to purchase natural gas from entities like Lightning . . . and, once it did so, to locate commercial customers to which it could sell the natural gas. Hess' business was not to profit on speculation that it could resell the purchased natural gas at higher prices based on favorable market swings, but rather to profit on mark-ups attributable to its transportation and other services provided to the end user of the natural gas. Because Hess entered into gas purchase contracts often at prices fixed well in advance of the execution date, it exposed itself to the serious risk that the market price of natural gas on the agreed-to purchase date would have fallen, leaving it in the position of having to pay a higher price for the natural gas than it could sell the gas for, even after its service-related markup. To hedge against this market risk, at each time it agreed to purchase natural gas from a supplier at a fixed price for delivery on a specific date, it also entered into a NYMEX futures contract to sell the same quantity of natural gas on the same date for the same fixed price. According to ordinary commodities trading practice, on the settlement date of the futures contract, Hess would not actually sell the natural gas to the other party to the futures contract but rather would simply pay any loss or receive any gain on the contract in a cash settlement. In making this arrangement, Hess made itself indifferent to fluctuations in the price of natural gas because settlement of the futures contract offset any favorable or unfavorable swings in the market price of natural gas on the date of delivery, allowing Hess to eliminate market risk and rest its profitability solely on its transportation and delivery services (at 359).

The court argued that by defaulting on the first half of the paired transactions, Lightning exposed Hess to the price risk that Hess had attempted to avoid. White \& Summers enthusiastically endorse this opinion: "In affirming Hess' jury verdict ... the Fourth Circuit agrees with our interpretation and arguments . . . for the proposition that 2-713 measures the contract market difference at the time of delivery not at time of repudiation in a repudiation case. Hurray for Judge Niemeyer” (\$7.6). The court failed to recognize, however, that if the remedy were based on the forward price at the time of the accepted repudiation, then Hess's neutral hedge position would have been maintained. Hess could have closed out its position at the then current price for future delivery. By using that price, Hess would have received the change in the value of the contract at the moment the repudiation was accepted. If Hess chose not to do so, it would bear the risk of subsequent price changes.

In other cases, courts have used the time of repudiation in determining damages. In Oloffson $v$ Coomer, a farmer (Coomer) promised in April to sell 40,000 bushels of corn to a grain dealer for delivery in October and December. However, in June Coomer informed Oloffson that, because the season had been too wet, he would not be planting any corn. The contract price was about $\$ 1.12$ per bushel and the price for future delivery at that time was $\$ 1.16$. Oloffson ultimately purchased corn at much higher prices after the delivery dates had 
passed (\$1.35 and \$1.49) and argued that its damages should be based on those prices. The court found that, given the nature of the market, a commercially reasonable time to await performance was less than a day. Ultimately, the court affirmed the trial court's use of the forward price at the time of repudiation (\$1.16) when calculating damages. Professor Jackson, using Oloffson to illustrate his argument, asserted that "contract law presumptively should adopt a general rule that an aggrieved buyer should cover at the forward price as of the date of the repudiation" (at 81-2).

While this is essentially the same position I have taken, Oloffson does raise one problem. The court noted that Oloffson had argued that he "adhered to a usage of trade that permitted his customers to cancel the contract for a future delivery of grain by making known to him a desire to cancel and paying to him the difference between the contract and market price on the day of cancellation" (at 875). Because Coomer had failed to give notice, Oloffson argued that Coomer could not take advantage of the rule and that damages should be measured by the price at the dates of performance ( $\$ 1.35$ and $\$ 1.49)$. The court rejected this because, it claimed, Coomer did not know of the alleged usage, and good faith required that Oloffson inform him of that usage. Remarkably, White \& Summers get this completely wrong. They reluctantly concede that "[t]he outcome of the case can be defended only on the ground that the contract was implicitly modified by the trade usage that prevailed in the corn market" (§7-3), but, as noted, the court rejected the trade usage (spot price) and chose instead the forward price. White \& Summers' preferred outcome, price at the time of performance, was not even in the running.

To call this result a trade usage is an understatement. In Cargill, Cargill had included in its confirmation a statement that the contract was subject to the rules of the National Grain and Feed Dealers Association (NGFDA). Stafford tried to argue that this additional term destroyed enforceability. The court, using a standard 2-207 "battle of the forms" analysis, held that the contract was enforceable, but that the NGFDA clause was not part of the contract. The court only said that the contract was not subject to the rules of the NGFDA, but it did not say what those rules were. The rule today is, no doubt, the same or similar to what it was when Cargill and Oloffson were decided: "cancel the defaulted portion of the contract at fair market value based on the close of the market the next business day" ( ( 28(A) (2017)). So, it appears that the standard rule in the grain trade (when courts are willing to recognize it) is to use the spot price, not the forward price. In these instances, the difference between the spot and forward price is unimportant. For a storable commodity (wheat, corn), the spot price plus the expected costs of storage is a good approximation of the forward price.

As a final example, consider Cosden Oil \& Chemical Co. v Karl O. Helm Aktiengesellschaft. Cosden, a producer of polystyrene, promised to deliver the 
product over a period of time to Helm, a trader. It delivered some, but because of production problems, it canceled the remaining orders. Anticipating the problem, Helm engaged in self-help, withholding payment for the polystyrene that had been delivered. In response, Cosden sued Helm, seeking damages for Helm's failure to pay for delivered polystyrene, and Helm counterclaimed for Cosden's failure to deliver. The jury found that Cosden had anticipatorily repudiated, and awarded Helm damages based on "the difference between the contract price and the market price at a commercially reasonable time after Cosden repudiated" (at 1069).

The main issue on appeal was which date should be used to determine the market price. The court considered three dates:

Cosden argues that damages should be measured when Helm learned of the repudiation. Helm contends that market price as of the last day for delivery —or the time of performance - should be used to compute its damages under the contract/market differential. We reject both views, and hold that the district court correctly measured damages at a commercially reasonable point after Cosden informed Helm that it was cancelling the [order] (at 1069).

The learned-of-repudiation date was properly rejected since the anticipatory repudiation doctrine gives the aggrieved party a reasonable period of time during which it can decide whether it should accept the repudiation. It should have enough time to weigh alternatives. The repudiation does not become a breach until it is accepted (or should have been accepted). For commodities traded in thick markets (as in Cargill and Oloffson), the time period might be measured in minutes - for others, like polystyrene, the period would be longer. So, there were really only two choices. By rejecting the time-of-performance date, Cosden is consistent with Oloffson.

There are three things worth noting about the decision. First, the court implies that the parties knew they were in a "rising market," not recognizing the difference between a rising market and a risen market. As I have emphasized, the parties do not know what the subsequent price path will be. Second, the court found the relevant price to be the spot price at the time the repudiation was deemed accepted, not the forward price. The court did not discuss the question, nor did it indicate that the two prices might have been different. In this instance, it seems more likely that it would have been more difficult to ascertain the forward price than in the grain cases.

Third is how the parties and the court treated "cover." Both parties identified particular transactions in the predecision period as cover transactions, Helm 
choosing those close to the performance date (the higher price) and Cosden those closer to the repudiation date:

At trial Cosden argued that Helm's purchases of polystyrene from other sources in early February constituted cover. Helm argued that those purchases were not intended to substitute for polystyrene sales cancelled by Cosden. Helm, however, contended that it did cover by purchasing large amounts of high impact polystyrene from other sources late in February and around the first of March. Cosden claimed that these purchases were not made reasonably and that they should not qualify as cover. The jury found that none of Helm's purchases of polystyrene from other sources were cover purchases ... We cannot isolate a reason to explain the jury's finding: it might have concluded that Helm would have made the purchases regardless of Cosden's nonperformance or that the transactions did not qualify as cover for other reasons. Because of the jury's finding, we cannot use those other transactions to determine Helm's damages (at 1076).

It is not surprising that the parties would identify the cover contracts that were most favorable to them. What is unfortunate is that this would be treated as a fact question. It reflects the notion that cover is a remedy that is alternative to the contract-market differential, rather than possible evidence of the price at the time of the breach. Helm, like Cargill, was a trader engaging in numerous transactions. To ask which of them was the cover contract presents the jury with a futile task. If the buyer did engage in subsequent transactions, the only question the jury should care about is whether details of those transactions would be useful in ascertaining the market price (spot or forward) at the time of the breach.

I do not mean to underestimate the difficulty in determining the damages. Problems existed even in the fairly thick markets I have discussed in this and the previous section. And if the market were thin there would be further difficulties. In Laredo Hides Co., Inc. $v H \& H$ Meat Products Co., Inc., for example, the contract was a variable output contract for all the hides $\mathrm{H} \& \mathrm{H}$ produced as a byproduct of its meatpacking business; with approximately nine months yet to go on the contract, the seller repudiated. Laredo claimed that because hides decomposed with age, it had to take the hides on a month to month basis. To determine the cover price, the court used the actual hide production of $\mathrm{H} \& \mathrm{H}$ in each month and applied the then current market price. Although that required looking at post-repudiation data, it might have been a reasonable method for determining the change in the value of the contract. The complexity is ratcheted up when dealing with long-term agreements, the subject of the next section. 


\section{LONG-TERM CONTRACTS}

If a buyer were to repudiate a 20 -year contract in year three, how should damages be reckoned? To further complicate the picture, often neither the price nor the quantity is fixed. The price might be indexed or subject to renegotiation; the agreement might even include a gross inequity, or hardship, clause that would allow a disgruntled party to appeal to an arbitrator or court to reset the price. The contract might have a mechanism that would allow one of the parties to terminate the agreement under certain circumstances. The buyer (in a requirements contract) or seller (in an output contract) may determine the quantity to be supplied. The contract might include a take-or-pay or minimum quantity clause, and that might be modified with a makeup clause.

I think it fair to say that neither the UCC nor the courts have been very good at dealing with these situations. "The drafters of the 1950s probably did not contemplate 20- or 30-year contracts," say White \& Summers, "but they clearly contemplated contracts where performance would occur after the time for trial. Section 2-723 is designed to deal with at least one issue in such cases. It instructs the court to base damages on the 'market price' at the date that the aggrieved party learns of the repudiation" (\$7-8).

White \& Summers interpret this to mean that "section 2-723 must be read to measure both the contract and the market price at the time the aggrieved party learned of the repudiation" (\$7-8). They would then use those prices for the duration of the contract. That is, if the contract price at the time of the repudiation was ten dollars and the market price had fallen to six dollars, then they would assume that for the next 15 or so years, those prices would remain constant. They do qualify this, however, by accepting any price information that would become available in the period between repudiation and trial. They recognize that "long term contracts for the sale of commodities such as oil, gas, coal, nuclear fuel and the like do not have fixed quantities for remote time periods" ( $\$ 7-8$, at 337). What to do? "We think a court should be generous in listening to an aggrieved party's expert testimony about projections" ( $\$ 7-8$, at 337). That does not give us much to go on.

The decisions tend to focus on the price of the product - the difference between the contract and market price. There are obvious complications for determining each since both the price and quantity will typically not be fixed for the life of the contract. Even if that problem could somehow be resolved, it still puts the focus on the wrong question. The relevant concern should be the change in the value of the contract at the time of the repudiation.

Ironically, there is a class of cases in which the courts have adopted the contract valuation approach without any fuss. When a contract is repudiated the seller can mitigate damages in one of two ways. The seller could continue 
to produce with damages being the expected difference in revenues in the pre- and post-repudiation worlds. But what if the expected future unit costs of production exceeded the expected prices? Then mitigation would entail shutting the project down. The seller's loss would be the expected future revenues less the expected cost of producing that revenue-lost profit. Courts have recognized this measure, treating it as obvious, without any reference to section 2-723. For example, in a casebook favorite, Northern Indiana Public Service Co. v Carbon County Coal Co. (NIPSCO), the seller closed the coal mine and Judge Posner concluded:

The loss to Carbon County from the breach of contract is simply the difference between (1) the contract price (as escalated over the life of the contract in accordance with the contract's escalator provisions) times quantity, and (2) the cost of mining the coal over the life of the contract. Carbon County does not even argue that $\$ 181$ million is not a reasonable estimate of the present value of the difference (at 279).

Courts have struggled with variable quantity contracts - take-or-pay and minimum quantity obligations. One issue, not of concern here, is whether these should be viewed as liquidated damages or penalties or something else. For assessing damages, the decisions do not always distinguish between two different problems - the anticipatory repudiation of the contract and a failure to perform a past obligation. After discussing the courts' muddled treatment of take-or-pay contracts, I will consider a Second Circuit decision in which the court was confronted with determining damages for the early repudiation of a 20-year contract. Next I will consider issues raised in another of Judge Posner's opinions-Lake River Corp. v Carborundum Co. I will conclude this section with a discussion of an English case involving the repudiation of a take-or-pay contract.

\subsection{Take-or-Pay}

For many years, natural gas prices were regulated at below market-clearing prices. One of the devices sellers used to charge a higher effective price was to include take-or-pay clauses with a high required "take." That is, a buyer might have to promise to pay for 90 percent of the contract quantity in any given year, even if it didn't take that much. After the industry was deregulated there was a substantial increase in production. When all energy prices fell in the 1980s gas prices plummeted too, and buyers wanted out. Many deals were renegotiated; in others buyers repudiated. More than 100 cases were filed (Medina et al. 1986, at 187). Since natural gas is a "good," the UCC applied and the courts attempted to apply the Code remedies, notably section $2-723$, to the problem. A key question for the courts was whether the buyer would be liable after 
repudiating the contract for the full price of the gas it had promised to take or a remedy based on the price differential. The decisions reflect how the courts have struggled to shoehorn the problem into the UCC boxes. In addition, the courts sometimes appear to conflate two separate issues: what would be the remedy if there were a shortfall in a single installment, and what would be the remedy if the buyer repudiated the entire contract?

\subsubsection{Manchester Pipeline Corp. v Peoples Natural Gas Co.}

The Manchester Pipeline Company, a seller of natural gas, entered into a contract with Peoples Natural Gas Company (PNG), a natural gas distribution company. "The Document provided for a term of ten years and contained detailed provisions concerning price, minimum 'take' obligations, determination of reserves, and the right of PNG to reduce the price paid for gas taken in order to remain competitive in the gas market" (at 1441). PNG repudiated in the first year. It lost its argument that there was not an enforceable contract and the court turned its attention to damages. The Court of Appeals reversed the trial court. It is instructive to see how the trial court framed the damage question in its jury instruction:

In order to determine the amount of damages: (1) for the first year, you may consider the evidence presented with regard to the difference between the agreed to price, if any, for the gas and the price obtained at resale of the gas to Scissortail Natural Gas Company, but that price is not conclusive, except to the extent that it reflects a standardized market price at the time and place defendant [PNG] would have had to take the amount of gas agreed, if there was an agreement, to be taken for the first year; plus (2) for the years two through ten, you may consider the evidence presented with regard to the difference, if any, between the market price for the gas at the time and place in the future when defendant [PNG] would have had to take that portion of plaintiff's [Manchester's] reserves as agreed, if agreed, and the agreed price, if any (at 1446).

Repudiation of the take-or-pay clause would not entitle the seller to the stream of future payments (the "pay" component of the take-or-pay). The post-repudiation damages would be based not on the price, but only on the price differential. The Court of Appeals agreed on that principle. The issue on which the trial judge was reversed was how those future prices should be determined. In his denial of PNG's motion for a new trial, the trial judge had said:

The Court acknowledges that in most circumstances the measure of damages for repudiation is determined according to the price of the goods prevailing at the time when the aggrieved party learned of the repudiation. Okla.Stat. tit. 12A. §2-723(a) (1981). Nevertheless, the unique circumstances of a gas purchase agreement with a take-or-pay obligation requires that the jury consider the extreme unpredictability of the future market. Giving the jury such discretion, provides the opportunity to find plaintiff is or is not entitled to recover damages for any alleged loss in the 
future. Because the nature of the gas market is uniquely nonstandard and the terms of gas purchase agreements are not easily analogized to commercial contracts in general, this Court finds the circumstances of this case, as presented at trial, fell within the scope of the commentary to section 2-723, that states other reasonable methods of determining market price or measuring damages are not excluded from use where necessary (at 1447).

PNG objected and the Court of Appeals agreed. This was not consistent with its understanding of section 2-723. The court cited the Code comment:

There are no previous Oklahoma decisions. This changes the rule as previously stated in Williston on Sales, Section 587, which says that when an action for anticipatory breach comes to trial before performance date the measure of damages is the difference between the contract price and the market value at the date fixed in the contract for performance. Thus, the jury must speculate by attempting to predict what the future market value will be. The Commercial Code rule is more certain and far easier to apply (at 1446).

Like White \& Summers, the court interpreted section 2-723(1) as requiring the use of the price at the time of repudiation for all future periods. This interpretation could lead to quite bizarre results in a period of high inflation. An alternative interpretation would be to use the expected future price structure (the projected price on various future dates). In effect, the buyer's obligation was to take a number of different commodities: gas in 1985, gas in 1986, gas in 1987, and so forth. Each of those commodities had an expected price at the moment of repudiation. Section 2-723 need not require that we lump them all together and apply a single price. Even if the court had resolved the price question correctly, it remained unclear how damages should have been assessed, since other features of the contract were not taken into account. Thus, there was no discussion of the future quantities. Nor was there any discussion of how the competitive pricing (or "market-out") clause should impact the results. Had the court focused on the change in the value of the contract, rather than just the price of gas, it would have at least posed the relevant question.

\subsubsection{Prenalta Corp. v Colo. Interstate Gas Co.}

Prenalta sold natural gas to Colorado Interstate Gas (CIG), an interstate pipeline, under take-or-pay contracts for a "term of 20 years and so long thereafter as gas is capable of being produced in commercial quantities from the gas leases and gas rights committed to the performance of this Agreement" (at 680 ). The contracts included a repricing arrangement anticipating deregulation:

Section 5.1(d) provides that in the event of deregulation of the price of gas sold under the contract, Prenalta would have the right to request a redetermination of the price during the first six months after the date of deregulation and during the 
six-month period preceding each five-year anniversary of the date of deregulation. Upon such request, the parties agreed to meet and determine a fair value of the gas (at 681).

The repricing option was the seller's, but the problem arose when prices collapsed and the buyer wanted out.

CIG continued to purchase gas under the contracts so there was no claim for repudiation. Prenalta's claim was for the years in which CIG had failed to take gas. It claimed that the contract was an installment contract with failures to pay for each installment, and that is how the court treated it. The court posed the issue as whether this was an "alternative contract" or a liquidated damages penalty provision. The court relied on Corbin in two respects. First:

If, upon a proper interpretation of the contract, it is found that the parties have agreed that either one of the two alternative performances is to be given by the promisor and received by the promisee as the agreed exchange and equivalent for the return performance rendered by the promisee, the contract is a true alternative contract. This is true even though one of the alternative performances is the payment of a liquidated sum of money; that fact does not make the contract one for the rendering of a single performance with a provision for liquidated damages in case of breach (at 689).

\section{Second:}

An alternative contract may be so drawn as to limit the power of the promisor to discharge his contractual duty by performing one of the alternatives to a definite period of time, after the expiration of which only the other alternative is available to him. After the expiration of the specified period, the obligation of the promisor becomes single and the contract is no longer alternative. In cases like this, the promisee must always estimate his damages on the basis of the second alternative .... Usually the alternative that is eliminated by the expiration of the period of time is the performance of service or the transfer of property, while the second alternative is the payment of a named sum of money (at 690).

Prenalta argued that the contract "clearly provides the contract remedy for breach, and that the measure of damages under the provision is the value of the 'quantity of gas which is equal to the difference between the Contract Quantity and Buyer's actual takes' for each year CIG has been in breach of the contracts" (at 687). The court agreed:

We find that the language of $\S 4.2 \ldots$ unambiguously expresses the intent of Prenalta and CIG to fashion a specific remedy for breach by requiring CIG to pay the value of the shortfall - the contract price multiplied by the difference between the contract quantity and the amount of gas actually taken during each one year period (at 688). 
Characterizing CIG's decision not to take gas as a "breach" is misguided. The failure to take was not a breach of the contract; it was simply CIG's exercise of its discretion under the contract. The only breach was CIG's subsequent failure to pay for the flexibility. For each period in which CIG chose to take less than the "take," it would be liable for the shortfall times the current price.

Corbin's characterization of the alternative performance works fine when it is applied to specific shortfalls. But what happens when a court tries to apply it to the future years of a repudiated contract? That question was the issue posed in Roye Realty \& Developing, Inc. v Arkla Inc. and Colorado Interstate Gas Co. $v$ Chemco, Inc. which came to opposite conclusions.

\subsubsection{Roye Realty \& Developing, Inc. v Arkla, Inc.}

The Oklahoma Supreme Court purported to answer a certified question: "What is the measure of damages under a take-or-pay gas purchase contract where the seller alleges an anticipatory repudiation by the buyer and buyer alleges that had it elected to 'take' gas, seller could not have physically delivered gas over the entire term of the contract?" (Roye Realty I, at 1152). Regarding the second part of the question, not relevant here, the court concluded: "If the seller is capable of performance on the date of the breach, the damages recoverable will not be diminished" (Roye Realty I, at 1160).

Roye Realty argued that "the damages for such repudiation should be based upon the 'pay' alternative under the contract and be calculated according to Arkla's minimum obligation from the date of the alleged repudiation through the end of the contract term" (at 1152). The argument took the Prenalta result and projected it forward - the deficiency payment obligation would provide the measure of damages for all the future years. The court disagreed-it invoked section 2-708 and section 2-723, claiming that the damages should be measured by the market-contract price differential at the time of repudiation.

Because the provisions of the UCC apply to gas purchase contracts, we hold that the measure of damages for anticipatory repudiation of both the take and the pay obligations in a take-or-pay gas purchase contract is the difference between the market price at the time when the aggrieved party learned of the repudiation and the unpaid contract price (Roye Realty I, at 1154).

After the repudiation, the seller would be freed of its obligation to deliver gas and could sell to others, in effect, mitigating the loss. "[B]y selling the gas on the open market and utilizing the $\S 2-708(1)$ measure of damages to get the difference between the market price and the contract price, Roye Realty will obtain the same price for its gas as if Arkla would have fully performed" (Roye Realty I, at 1157). The court, as noted, used the contract-market price differential in the first period (section 2-723) to determine the future price. 
What would it use for the future contract price and future contract quantity? Neither of these metrics would be known on the date of repudiation in a typical take-or-pay contract. The court was silent on both, although I suspect that if pushed it would have assumed that these would have remained the same over the remaining life of the contract. Nor did the court take into account any other features of the contract-for example, whether either party had an early termination option or whether there was a makeup clause. Nonetheless, the court was satisfied that it had answered the first part of the certified question: "that the measure of damages for repudiation is provided in the UCC" (Roye Realty I, at 1159).

As it turned out, it was not necessary to answer the first question because the trial court eventually held that the failure to pay was not a repudiation of the entire agreement after all; it was only a failure to pay for an installment (Roye Realty II). The Court of Appeals for the Tenth Circuit concurred in an unpublished opinion.

\subsubsection{Colorado Interstate Gas Co. v Chemco, Inc.}

Unlike Arkla, the court in Colorado Interstate Gas Co. v Chemco, Inc. appeared to find that damages for the future take obligation would be measured by the price, not the price differential. I say "appeared to" because some ambiguity exists regarding the post-trial damage measurement. In 1985, after the market price of gas had collapsed, the buyer in a take-or-pay contract, Colorado Interstate Gas Company (CIG), claimed that the contract allowed it to terminate. In a bifurcated trial, CIG lost its claim on liability. In the second phase, there were two questions. First, how much should CIG have to pay for shortfalls in the period prior to the repudiation? Second, how much should CIG have to pay for the post-repudiation years?

A third issue might have rendered the second question moot. "After the phase I finding of liability, CIG requested the resumption of full performance from all committed wells effective May 2, 1988" (Chemco I, at 1238). "Chemco responded with a request for 'reasonable written assurances' that CIG would 'consider the contract in force and effect' and intended to 'perform [CIG's] obligations under it for the remainder of its term" (Chemco I, at 1239). The jury found that the demand for assurance was justified and that CIG's response did not provide adequate assurance.

The jury found damages of about $\$ 3$ million, about 10 percent of which were for the post-1988 (trial) period. The court does not say how the post-1988 damages were measured. In the court's only discussion of damages it favored the price remedy: "The trial court further instructed the jury that, if they found actual damages, they should award 'as such actual damages all take-or-pay payments due Chemco under the terms of the contract" (Chemco I, at 1234). Citing Corbin, the court stated: “Once the 'take-and-pay' alternative 
expired . . . performance becomes the monetary payment of a sum unambiguously defined by the contract 'the difference between the [contract quantity] and the Buyer's actual takes"' (Chemco I, at 1237). The court appears to have treated "take-and-pay" as synonymous with "take-or-pay"; as noted below, a take-and-pay contract is different, although the remedy for a repudiation would be the same.

That is clearly correct for the pre-repudiation period. "Accordingly, we hold that under the facts of this case the remedy for breach of the alternative performance obligation is the payment of damages equivalent to the value of the remaining performance obligation" (Chemco I, at 1236). So, it would seem that CIG would be liable for the pay alternative for the duration of the contract.

But it is not clear that the court viewed CIG as having repudiated the contract. Did CIG's wrongful claim of a right to terminate entail the total breach of the contract, and did its subsequent request for the resumption of full performance after its loss of the liability phase in 1988 mean that the original contract was still in force? Had CIG only failed to make installment payments, the entire contract would have remained in force, and there would have been no post-trial damages. In a subsequent case based on the same contract (Chemco II), the court held that "the parties again had performance obligations under the contract, which both had recognized as valid after the April 1988 trial court ruling" (Chemco II, at 834). So, perhaps Chemco does not deal with an anticipatory repudiation at all and it is not, therefore, contrary to Arkla. I think it fair to say that the opinion reflects the difficulties courts have had fitting a take-or-pay contract into the UCC boxes, although it is probably more muddled than most.

\subsubsection{Lost Volume}

A few courts have invoked section 2-708(2) (the lost volume seller) to justify using the price rather than the price differential to measure damages: "[T]hat gas which Plaintiff was required to pay for if not taken would be unavailable to Defendants to sell upon the expiration of their contract with Plaintiff ... Defendants cannot be required to relinquish this substantial benefit under the contract as part of its duty to mitigate damages" (Brooke 1992, at 1484-5).

The "benefit," according to one commentator, A.F. Brooke, was the right to sell the same gas twice:

This possibility of selling the gas twice was seen as a valuable right. The court concluded that it would be inappropriate to require the producer to have mitigated its damages by resale ... The take-or-pay producer should not be required to mitigate its damages by reselling since that would entail the sacrifice of the substantial right to "sell" the same gas twice (Brooke 1992, 1485). 
The double payment argument also was raised in the Chemco II dispute: "CIG argues that this puts Chemco in a better position than if the contract had been performed because it results in Chemco's receiving the full contract price and also retaining the gas for resale" (Chemco II, at 833).

Brooke concluded that the argument only applied to the past shortfalls: "[T] he producer is entitled to contract-market damages only when the pipeline has made an anticipatory repudiation of the contract before failing to take ... [W] hen the contract still admits of alternative performance, the correct measure of damages is the one least costly to the breacher" (Brooke 1992, 1486-7). It is not clear whether a court would have also concluded that its remedy applied only to past shortfalls, or if it meant to apply it to future take obligations as well.

The Prenalta-CIG dispute also involved a group of "take-and-pay" contracts under which the pipeline would be required to take and pay for a minimum contract quantity of gas annually. The court determined that for this type of contract the appropriate remedy was to treat Prenalta as a lost volume seller:

The parties agree that [Wyoming's version of UCC §2-708(1)] . . would not put Prenalta in as good a position as if CIG had performed because the price under the contracts is less than the market price at the time and place of tender. Prenalta's remedy, therefore, is provided by [Wyoming's version of UCC §2-708(2)] (Prenalta, at 691).

Therefore, it held, Prenalta should have the opportunity to offer evidence of lost profits. The court failed to appreciate the difference between take-or-pay and take-and-pay contracts. In a take-or-pay contract, if there were a shortfall in one time period, the buyer would owe the price times the quantity; the seller would be free to sell to other customers without offsetting any of the sales. The contract would remain alive, unless the buyer chose to repudiate. In contrast, in a take-and-pay contract, the failure to take the contract amount in a given year would be a breach of an installment of the contract; damages would be the contract-market differential. If the shortfall "substantially impaired" the value of the contract as a whole, the seller would have the option of declaring a breach of the whole.

\subsubsection{Summing Up}

In long-term take-or-pay contracts, the UCC works fine for dealing with a shortfall in an ongoing contract. The buyer would simply pay the contract price multiplied by the shortfall and both parties would continue to be bound by the contract. Courts get there in various ways, and the reasoning is not always transparent, but they do seem to figure it out. However, the UCC is, as White \& Summers asserted, inadequate for dealing with repudiation of 
long-term contracts. It provides an answer — not necessarily a good answer- to the question of what price of the goods should be used (mainly section 2-723). It provides no coherent answer to the question of how (or even if) future quantities should be determined. It ignores significant features of the contracts such as early termination rights and price redetermination rights. Most decisions seem to conclude that for the post-decision period damages should be based on the difference between some measure of future contract and market prices. But the case law seems a bit hazy on the treatment of a repudiation and whether it should be treated differently from a shortfall in a particular installment.

The section 2-723 inquiry focuses on the wrong price. We could adapt section 2-723, recognizing that what we are looking for is not a single price, but the set of forward prices - that is, today's price for delivery on each of the future dates. That set of prices would be implicit in the valuation of the contract at the repudiation date. And that highlights the key point. The concern should not be with the change in the price of the gas, but with the change in the value of the asset - the contract - at the time of the repudiation. The contract's value encompasses all the nuances that the section 2-723 inquiry fails to reach. Medina et al. (1986, at 201) make this point as well: "The payment made is for the market value of the gas contract, not for the purchase of reserves. Therefore, after payment of the damages, the producer will still own the gas although the reserves will no longer be contracted." The value depends on, among other things, the nature of the take-or-pay obligation, the price adjustment mechanism (including a possible market-out), and the termination options. Because termination of the seller's obligation frees it to sell the gas to others, the remedy would be based on the expected market-contract price differential; it incorporates mitigation by resale. Or, if the seller is better off by not producing, the damages would be the difference between the future revenue stream and the costs avoided by not having to produce. In effect, we ask: how much would the buyer be willing to pay to walk away?

I do not mean to suggest that this would be an easy task; it would almost certainly require some sophisticated work by economic experts. But I should note that this is an exercise parties routinely engage in when negotiating a settlement. In the period in which these cases were litigated, the overwhelming majority of the natural gas take-or-pay contracts were renegotiated, with many (probably most) including a lump sum payment to extricate the buyer from the deal. And, as the Second Circuit Court of Appeals said in the next case, this is the sort of exercise the parties engaged in when entering into the deal in the first place. 
In November 2000, American Electric Power Company (AEP) entered into a Power Purchase and Sale Agreement (PPSA) with Tractebel Energy Marketing, Inc. (TEMI). AEP would build a cogeneration plant in Plaquemine, Louisiana that would supply steam to Dow Chemical and electric power to TEMI. The PPSA term was for 20 years. Because Dow needed large quantities of steam, and because the steam and electricity were jointly produced, the contract required that TEMI take a substantial amount of electricity. The contract included a "must-take" provision. It also included a minimum guarantee of $\$ 50$ million and a mechanism by which either party could request that the guarantee be increased if it believed the guarantee had become inadequate. AEP spent about $\$ 500$ million building the facility; before the facility was on line, the market for electricity collapsed and TEMI wanted out. AEP requested that the guarantee be increased to reflect the new conditions and TEMI refused.

To show that AEP had reasonable grounds for believing that the guarantee was inadequate it had to show that the present value of gains and losses exceeded $\$ 50$ million. This was not too hard because there was evidence that, prior to repudiation, TEMI had produced internal calculations showing termination payments in excess of $\$ 600$ million. The court concluded that TEMI's refusal was unreasonable and that TEMI had repudiated the agreement; it then confronted the damage assessment issue.

Each side provided expert testimony on AEP's lost profits. AEP's witness concluded that the present value of its losses over the 20-year period was between $\$ 417$ and \$604 million, with the most likely case being \$520 million. TEMI's expert claimed that AEP suffered no loss. In effect, he concluded that the repudiation was a gift to AEP, so TEMI should pay nothing. The trial judge was not impressed by either expert: "I found both experts provided unreliable testimony and worse yet, it appeared to be clouded by their obvious advocacy, to paraphrase a popular show tune, on behalf of the lady they came in with" (Tractebel II, at*4). But even if they had done impeccable work, he would not have accepted it; it would have been too speculative:

In order to know what AEP's revenues would be over the next twenty years, one would have to be able to presage a vast and varied body of facts. Any projection of lost profits would necessarily include assumptions regarding the price of electricity and the costs of operating over twenty years. One would also need to surmise what competing forms of energy such as coal and nuclear energy would cost over the same time period. Also factoring into this calculation are the political and regulatory developments over twenty years, population growth in the Entergy region, and technological advances affecting the production of power and related products. With so many unknown variables, these experts might have done as well had they consulted tealeaves or a crystal ball (Tractebel $I$, at *11-12). 
So, he concluded, the lost profits damages were zero. He also claimed that since the plant had not yet operated, this was a "new business," and because New York was one of the few jurisdictions with a per se rule against finding lost profits for a new business, there could be no lost profits. I take up the "new business" issue in Chapter 12.

The trial judge treated the lost profit claim as one for consequential damages, which, under New York law, require a higher standard of proof than general damages. In his reconsideration order he held that "even under the far more flexible standard for general damages, AEP failed to meet its burden of proof." The Second Circuit Court of Appeals disagreed on both counts. The damages were general, it held, and if proof were disallowed because of all the confounding factors, no victims of a repudiation of a long-term contract could ever be compensated:

Not a single product or service exists for which a company's profit margin, over time, is unaffected by fluctuating supply and demand, changes in operating costs, increased competition from alternatives, alterations to the relevant regulatory regime, population increases or decreases in the targeted market, or technological advances. The variables identified by the district court exist in every long-term contract. It is not the case that all such contracts may be breached with impunity because of the difficulty of accurately calculating damages (Tractebel III, at 112).

The Court of Appeals found that AEP's “lost profits" was the appropriate damage remedy. It is important to recognize that "lost profits" should not be viewed as a separate element of damages. It is the change in the value of the asset - the contract. That would be the expected future revenues had the contract been performed less the amount AEP would receive in the plant's next best use (that is, mitigation by selling at the new, lower expected market price). Of course, since the electricity prices had collapsed, one thing was clear-the value of the contract had to have increased. The TEMI expert's conclusion that there were no damages could not possibly have been correct.

The contract did include a mechanism for assessing a market-related price to determine a termination payment. The market price was to be "based on broker, dealer or exchange quotations" for the immediately ensuing "five year period ... or such longer period for which a market is available" (PPSA $\S 7.1 .2$ ). Section 7.1.2 also specified that, to calculate the projected termination payment, the market price of the products sold to TEMI "shall be based on broker, dealer or exchange quotations" for five years, escalated at 3 percent per year through the remaining term of the PPSA (Tractebel $I$, at *4).

Because the market was illiquid, there were no observable market prices; to make up for that, AEP used "two-ways" to generate forward prices for the five years. In a two-way, AEP would quote both an offer to buy and to sell: “AEP's bids and offers were fully executable, [so] if another party decided to 
act on AEP's numbers, AEP would actually follow through and consummate the transaction" (Tractebel I, at*4). None did, but the court concluded that this was a plausible form of market price discovery, one that TEMI itself had used in the past.

The Court of Appeals concluded that while the projection of lost profits would be difficult, it is, in effect, the same exercise in which the parties engaged when negotiating the 20 -year contract in the first place:

It is no less speculative for the district court to determine AEP's loss over the twenty-year period than it was for TEMI to calculate its expected profit from the PPSA at the time it entered into the agreement. The district court stated that the parties' respective experts could "have done as well had they consulted tealeaves or a crystal ball." If it is true that projecting profits over twenty years is so absurdly speculative that economists can do no better than fortune tellers, it would have been imprudent for the parties to enter a contract for such a long period in the first place. The reality, however, is that long-term contracts are entered into regularly, and a degree of speculation is acceptable in the business community (Tractebel III, at 112).

Lake River Corp. v Carborundum Co.

Carborundum promised to pay Lake River for bagging a minimum quantity of its product (Ferro Carbo) over a three-year period. Lake River stood ready to provide bagging services for up to 400 tons per week for three years. Carborundum agreed to pay for a minimum of 22,500 tons (a bit over one third of the maximum) for around $\$ 533,000$. Because of a decline in the market for Ferro Carbo, Carborundum ended up only requiring Lake River to bag about half the minimum. Lake River sued for payment for the other half-the contract price times the shortfall. The issue as framed by the parties and the court was whether the minimum quantity clause was for liquidated damages (enforceable) or a penalty (unenforceable). Judge Posner concluded that it was an unenforceable penalty. I have argued elsewhere that this was wrong (Goldberg 2015a, ch. 7). The minimum quantity clause was neither a penalty nor a liquidated damages clause. The contract should have been interpreted as Lake River granting Carborundum flexibility, and that the minimum quantity was an element in the price Lake River received for granting that flexibility.

In its brief, Carborundum presented a hypothetical. What if during the entire three years Carborundum had delivered not even one pound? It would be absurd, it argued, to bill Carborundum for the entire 22,500 tons $(\$ 533,000)$. But, given that Lake River would have had to maintain its ability to bag 400 tons per week for the entire period, it would not be at all absurd. That was the price Carborundum paid for flexibility. Lake River would have fully per- 
formed by holding itself ready for the entire three years. The only breach, as in Prenalta, would have been Carborundum's failure to pay.

In the course of his opinion, Judge Posner posed a similar hypothetical, but there was a subtle difference. "Suppose to begin with that the breach occurs the day after Lake River buys its new bagging system for $\$ 89,000$ and before Carborundum ships any Ferro Carbo." He, like Carborundum, suggested that compensating Lake River would have resulted in a huge windfall and, therefore, it would be a penalty. There is, however, a fundamental difference between the actual case, in which the three-year term had expired, and Posner's hypothetical one, in which one party repudiated prior to expiration. Would Carborundum still have to pay for the 22,500 tons or would Lake River have been required to mitigate its damages? Judge Posner claimed that Lake River raised this argument: "Lake River argues that it would never get as much as the formula suggests, because it would be required to mitigate its damages" (at 1291). He rejected the argument because, he claimed, it would undercut the virtues of liquidated damages.

Properly understood, Lake River's compensation, in this hypothetical, would not be $\$ 533,000$. The question that should have been asked regarding the repudiation was, again, what was the change in value of the asset - the contract? In effect, mitigation would be baked into the damage measurement. That is, upon repudiation Lake River no longer would have to remain ready to bag any goods. In that sense it could mitigate by using its resources for other purposes. To take an example even more extreme than Judge Posner's, suppose that the day after signing the agreement and before any investments had been made, Carborundum repudiated. And suppose further that there had been no change in the market. This is really no different than the simple breach of a widget contract in which the price had not changed. The price of the contract would remain unchanged and damages would be zero.

\subsection{Take-or-Pay in England}

In M\&J Polymers Ltd $v$ Imerys Minerals Ltd, an English court was confronted for the first time with the question of whether a take-or-pay clause was unenforceable because it was a penalty. The contract, for the supply of chemical dispersants, was for three years with monthly minimum quantities. The buyer repudiated the contract but it had not paid for the minimum quantities prior to the repudiation. The court framed the issue:

This issue relates to the claimant's claim in respect of the shortfall of deliveries ... until the (repudiatory) termination of the supply contract in May 2006. The claimant claims the price of such shortfall, pursuant to the take or pay clause, article 5.5. The defendant asserts that the claim pursuant to the take or pay clause amounts to 
a penalty, and that the claimant must be limited to a claim for breach of the defendant's obligation under article 5.3 to order the specified minimum quantities. It is common ground that, once the contract was terminated, [that is] after May 2006 and in respect of the balance of the supply contract, the claimant's claim is in damages only, as it did not seek to keep the contract alive ( $\$$ 68-9).

That is, the court (and the parties) took for granted that the repudiation did not entitle the seller to the contract price on the remaining quantities. On the issue that it did face, it had no difficulty rejecting the notion that the take-or-pay constituted a penalty. In both respects the decision is consistent with my interpretation of both the actual and hypothetical versions of Lake River. That is, it would award full payment of the price for past shortfalls and the contractmarket differential for the post-breach sales.

\subsection{Summing Up}

The "take-or-pay" and "minimum quantity" contracts are basically the same. The former sets a series of minimum obligations and the latter sets a single obligation. In a take-or-pay contract, each period can be treated as an installment; so long as the court does not find the contract terminated (an anticipatory repudiation), the contract remains in force. If after the year (or some other relevant time period) has passed the buyer had failed to take the required amount, the buyer would have to pay the price multiplied by the shortfall, as the court found in Prenalta. Likewise, if the parties agreed on a minimum quantity over a fixed period, if the buyer failed to reach the minimum, then the buyer should be liable for the same thing - the price multiplied by the shortfall. That was the result rejected by Judge Posner in Lake River. The take-or-pay contract has multiple periods while the minimum quantity contract has but one. Analytically, there is no difference.

If a buyer were to repudiate a take-or-pay contract, the damages would not be the price multiplied by the shortfall. The damages should be the change in value of the contract at the moment of repudiation - the present value of the difference in the expected cash flows. That would be based on the projected market-contract price differential or the lost profits, depending on whether the seller could do something else with the goods in the remaining years. We could call it mitigation, but it is more straightforward to simply recognize it as an element in finding the change in the value of the contract. In effect, that is what the court did in Tractebel. That seems to be the direction the courts were taking in both Manchester Pipeline and Roye Realty, although both decisions were a bit confused. Repudiation of a minimum quantity contract, as in Posner's hypothetical, should be no different. The major distinction is that it 
would be a lot easier to assess damages because there would be less difficulty in determining both the quantity and the contract-market differential.

\subsection{Why Damages at Time of Breach?}

When I presented an earlier version of this chapter in Germany, the participants proposed two alternatives to reckoning the damages for the repudiation of a long-term contract at the time of the breach. Why not award specific performance? Or, alternatively, why not wait until the full performance was due, perhaps requiring the non-breacher to sue multiple times? In NIPSCO, discussed above, the buyer asked for specific performance, but Judge Posner rejected it:

Indeed, specific performance would be improper as well as unnecessary here, because it would force the continuation of production that has become uneconomical ... No one wants coal from Carbon County's mine. With the collapse of oil prices, which has depressed the price of substitute fuels as well, this coal costs far more to get out of the ground than it is worth in the market. Continuing to produce it, under compulsion of an order for specific performance, would impose costs on society greater than the benefits. NIPSCO's breach, though it gave Carbon County a right to damages, was an efficient breach in the sense that it brought to a halt a production process that was no longer cost-justified (at 279).

It would indeed have been inefficient for Carbon County to continue producing coal that NIPSCO couldn't use. But, Judge Posner noted, specific performance does not require actual performance. It would simply give the buyer a bargaining chip, and the seller would have to pay to lift the injunction. If there were no holdup issues, the parties' negotiations would determine the value of the contract better than an ex post battle of the experts. If, however, holdup were a significant problem, as would have been the case in NIPSCO, the specific performance remedy becomes less attractive.

In cases in which the holdup potential is low, the specific performance remedy might be superior to the damage remedy. The holdup potential would be lower in the situation in which the claimant could only sue seriatim for past failures; we should expect that, because the holdup threat is weaker, the parties might be able to negotiate a settlement that would reflect their expectations about the future. The settlement value would depend upon more than the expected future damages; it would also reflect the expected costs of repeated suits and the vulnerability of each of the parties to the timing of the damage payments. It is at least plausible that parties might prefer a regime in which multiple suits would be required to one in which the damages are measured once and for all. The fact that the suits would be required does not, of course, mean that there would in fact be multiple suits; it would simply provide the 
basis for settlement of the future claims. To be clear, I am not proposing that requiring multiple suits (rejecting anticipatory repudiation in long-term contracts) would be superior; I am only raising the possibility that this might be workable.

\section{CONCLUDING REMARKS}

What does it mean to make the victim of a contract breach whole? I have argued that the contract should be viewed as an asset and the claimant's loss would be the change in value of that asset. Damages could be measured at the time of the breach, using only information available at that time. Or damages could be reckoned at some future date, in particular the decision date, utilizing post-breach data. Given that the value of the asset (the contract) can fluctuate, it should not matter which we choose, so long as that choice is made before the dispute arises. I think the breach date is more straightforward, but the more important point is that the question should be off the table once a dispute arises. Essentially, the choice of the date of valuation should be under a "veil of ignorance."

The contract as asset approach proved useful even in the case of a breach of a simple commodity contract. But the big payoff was for the anticipatory repudiation of long-term contracts with termination dates after the decision date. For a commodity contract breached on the date of performance, the remedy would simply be the market-contract differential on that date. The only issue in this type of case is how to treat "cover." My claim was that cover should not be viewed as an alternative remedy (and certainly not as a preferred alternative remedy), but as evidence of the market price. An alleged cover transaction that occurs immediately after the breach calling for the same quantity of an identical commodity at the same location would obviously be acceptable. The further it deviates from this ideal, the weaker the presumption that it reflects the aggrieved party's loss.

Long-term contracts present two different issues: a shortfall in an individual installment and an anticipatory repudiation of the entire agreement. For the shortfall, whether the contract is an installment in a take-or-pay agreement or a minimum quantity agreement for which the seller brought suit after the term expired, the remedy would simply be the price multiplied by the shortfall. The only breach would be a failure to pay - the value of the contract itself would not be impaired. For the repudiation, the problem is to ascertain the change in the value of the asset - the contract. The present discounted value of the change in value will reflect expectations regarding the market price, the contract price, quantity, cost of production, and, perhaps, future events that might result in early termination of the contract. Both lost profits and mitigation are captured by the valuation of the contract. By focusing on the change in the 
value of the contract-asset, the approach delineates which "lost profits" matter. So, for example, if, as in the Lake River hypothetical, a buyer repudiated a contract before there had been any reliance and before the market had changed, a court might erroneously find lost profits as the projected quantity times the seller's markup. I would argue that the proper damage measure in such a case would be zero, or nominal at best.

The basic methodology for valuation is now standard, but, as the divergent valuation estimates in Tractebel illustrate, there is a lot of room for experts to disagree. To get some indication of the potential for disagreement, we can return to Widgetco. However, instead of considering a failure to deliver shares of stock, suppose that Widgetco had been acquired, but that some minority shareholders have asked for an appraisal. The shareholders and the corporation then present expert testimony on the value of the shares. The techniques used for this exercise are essentially the same as would be employed to ascertain the contract damages.

About two decades ago, Wertheimer (1998, at 630-1) collected data on expert valuations in Delaware appraisal cases; his data show substantial divergences, some by a factor of ten or more. In a more recent study, Choi and Talley (2018) found that the gap had declined, but was still substantial. As then Vice Chancellor Allen asserted, "if the court will ultimately reject both parties DCF [discounted cash flow] analysis and do its own, the incentive of the contending parties is to arrive at estimates of value that are at the outer margins of plausibility - that essentially define a bargaining range" (Cede at *26). If the damage estimates of experts in long-term contract cases are destined to be at the outer margins of plausibility (and perhaps beyond), are there some techniques available to courts or arbitration panels to narrow their disagreement?

I will note three. First, neutral experts could be appointed; their role could be defined in various ways. They could critique the reports of the party-appointed experts or, perhaps, perform their own damage studies. Second, some courts, notably in Australia, and some arbitration panels have used "hot-tubbing" (Kao et al. 2010). There are a number of variations on this practice; for example, the experts could question each other or arbitrators could question the witnesses directly. The presumption is that the process would constrain the experts and narrow the range of their disagreement.

Third, the court or panel could adopt a form of "final-offer arbitration." The court's choice would be limited; it could not mix and match pieces of the different reports, split the baby, or impose any estimate proffered by neither party. It could choose only one party's measure. When Vice Chancellor Allen attempted to implement it in an appraisal proceeding, he told both parties "that it was [his] inclination and [his] temperamental approach . . . to want to accept one expert or the other hook, line and sinker" (Gonsalves, at 358). The logic is simple enough. If a party were to get too aggressive, the decision maker 
would choose the other side's estimate. Recognizing that, both parties have an incentive to take a less aggressive position. Their estimates should converge, thereby narrowing the range of disagreement, or, in Allen's words, return us from the "outer margins of plausibility."

There is no question that estimating the damages in long-term, complex agreements will be difficult and that courts, arbitration panels, and (gasp) lay juries will be confronted with reports and testimony that will make their eyes glaze over and their heads hurt. Still, it has to be done, unless we just want to label all such damages as "speculative," and deny all recovery. Perhaps in the future, parties will include some guidelines (methods for determining prejudgment interest rates, discount rates, projected prices, and so on) to constrain the experts in their damage estimates. My concern in this chapter has been with the conceptual framework. The nuts and bolts of damage estimation I leave to another day. 